\title{
РАСШИРЕНИЕ ГЕНЕТИЧЕСКОГО РАЗНООБРАЗИЯ СОРТОВ ЯРОВОЙ МЯГКОЙ ПШЕНИЦЫ ПО УСТОЙЧИВОСТИ К БУРОЙ РЖАВЧИНЕ (Puccinia triticina Eriks.) В НИЖНЕМ ПОВОЛЖЬЕ
}

\author{
Е.И. ГУЛЬТЯЕВА ${ }^{1}$, С.Н. СИБИКЕЕВ ${ }^{2}$, А.Е. ДРУЖИН ${ }^{2}$, Е.Л. ШАЙДАЮК 1
}

Бурая (листовая) ржавчина (возбудитель Puccinia triticina Erikss.) - значимое заболевание озимой и яровой пшеницы в Российской Федерации и других странах. Успешная защита пшеницы от бурой ржавчины возможна только за счет увеличения генетического разнообразия создаваемых сортов. Оно может быть достигнуто посредством эффективного комбинирования известных генов устойчивости или использования в гибридизации доноров новых генов устойчивости (Lr-генов), источниками которых служат виды родов Triticum и Aegilops. В НИИ сельского хозяйства Юго-Востока традиционно проводятся работы в этом направлении. На основе высокопродуктивных сортов яровой мягкой пшеницы собственной селекции (Прохоровка, Саратовская 29, Саратовская 55, Саратовская 68, Саратовская 70, Саратовская 73, Саратовская 74, Л503, Л505, Добрыня, Фаворит, Белянка, Воевода) создан перспективный селекционный материал, высокоустойчивый к бурой ржавчине. В представленном исследовании впервые рассмотрено генетическое разнообразие перспективных линий яровой мягкой пшеницы по генам устойчивости в условиях Нижнего Поволжья. Цель работы заключалась в изучении генетической детерминации признака устойчивости к бурой ржавчине у новых перспективных интрогрессивных линий яровой мягкой пшеницы, выявлении изменений в составе современных популяций возбудителя бурой ржавчины и определении перспективности использования имеющегося набора $\mathrm{Lr}$-линий для селекции на устойчивость к бурой ржавчине в Поволжье. Материалом служили 42 интрогрессивные линии, полученные на основе высокоадаптивных сортов саратовской селекции (НИИ сельского хозяйства Юго-Востока) и родственных мягкой пшенице видов. Донорами $L r$-генов были линии Thahcher с генами Lr24, Lr29, Lr36, сорта с Lr37 и образцы видов Triticum dicoccum, T. kiharae, T. timopheevii, T. durum, T. petropavloskyi, T. persicum, Aegilops tauschii, Secale sereale и Agropyron elongatum. Идентификацию генов устойчивости к бурой ржавчине проводили с использованием фитопатологического метода и ДНК маркеров. Изученные линии яровой мягкой пшеницы характеризовались высоким генетическим разнообразием по устойчивости к бурой ржавчине. Среди них присутствовали носители известных $L r$-генов, ранее не использованных в селекции яровой пшеницы в России (Л4 - Lr29), и носители предположительно новых $L r$-генов, переданных от T. durum (Л8, Л39 - Lr19 + LrTdur, Л25, Л19, Л11 - Lr10 + Lr19 + LrTdur), T. persicum (Л38 - Lr19 + LrTpers), T. timopheevi (Л49 - Lr10 + LrTtim), Ae. tauschii (Л6 - Lr19 + LrAtau) и T. kiharae (Л33 - Lr3 + Lr19 + LrTkh). У Л10, Л13, Л46, Л24, Л48, Л5 и Л9 определена эффективная комбинация генов $L r 19+\operatorname{Lr} 26 ;$ у Л2, Л28, Л29 - Lr10 + Lr19 + Lr26; Л42 Lr19 + Lr37; Л44 - Lr19 + Lr26 + Lr39; Л3 - Lr19 + Lr37 + Lr6Agi; Л4 - Lr19 +Lr6Agi; Л7 Lr10 + Lr26 + Lr6Agi; Л45 - Lr10 + Lr19 + Lr39 + Lr6Agi; Л40 - Lr10 + Lr39 + Lr6Agi. Успех селекции пшеницы на устойчивость к бурой ржавчине невозможен без изучения генетического состава популяции патогена по признаку вирулентности. Мы охарактеризовали вирулентность саратовской популяции $P$. triticina в 2017 и 2018 годах. Инфекционный материал был собран с растений восприимчивых сортов пшеницы, произрастающих в общем посеве с изучаемым набором линий. Высокой эффективностью обладали гены $\operatorname{Lr} 9, \operatorname{Lr} 24, \operatorname{Lr} 28, \operatorname{Lr} 29, \operatorname{Lr} 39, \operatorname{Lr} 42, \operatorname{Lr} 45$, Lr47, Lr50, Lr51, Lr53, Lr6Agi (тип реакции 0 и 0;). Линии с Lr28, Lr29, Lr39, Lr51, Lr6Agi также характеризовались высокой устойчивостью в полевых условиях. Следовательно, весь набор этих генов может представлять интерес для расширения генетического разнообразия выращиваемых в Поволжье сортов пшеницы. Изоляты, вирулентные для линии TcLr19, имели умеренную представленность (в 2017 году - $16 \%$, в 2018 году - $20 \%$ ). Все изоляты, вирулентные для носителей $\operatorname{Lr} 19$, оказались авирулентными к $\operatorname{Lr} 26$, что подтверждает эффективность этой комбинации генов в защите пшеницы от бурой ржавчины. Таким образом, создан новый селекционный материал, сочетающий устойчивость к бурой ржавчине с адаптивностью к неблагоприятным факторам среды, продуктивностью и высоким качеством зерна. Выявлены линии с эффективными комбинациями известных $L r$-генов, а также комбинациями известных $L r$-генов с предположительно новыми чужеродными генами.

Ключевые слова: Puccinia triticina, вирулентность, авирулентность, Triticum aestivum, интрогрессивные линии, $L r$-гены.

\section{Бурая (листовая) ржавчина (возбудитель Puccinia triticina Erikss.) -}

\footnotetext{
* Исследования выполнены при финансовой поддержке проекта РФФИ № 18-016-00170.
} 
экономически значимое заболевание мягкой пшеницы во многих странах мира, в том числе в Российской Федерации. В Поволжье болезнь проявляется практически ежегодно. Эпифитотии наблюдаются в среднем один раз в три-четыре года. Потери урожая могут достигать 20-30\%, при орошении - $35 \%$, при этом значимо снижается содержание в зерне белка и клейковины (1-3). Анализ хронологии эпифитотий патогена свидетельствует о том, что в Поволжье ущерб от листовой ржавчины в последние время стал сильнее, чем в первой половине XX века (4). Защита сортов мягкой пшеницы от этого заболевания становится приоритетной Защита сортов мягкой пшеницы от этого заболевания становится приоритетной. При этом основное направление - увеличение генетического разнообразия высокопродуктивных и адаптированных к условиям юго-востока России сортов яровой мягкой пшеницы местной селекции с использованием видов рода Triticum или Aegilops либо посредством эффективного сочетания известных $L r$-генов.

Первые попытки создания интрогрессивных сортов пшеницы с использованием близкородственных видов предпринимались еще в первой половины XX века, когда проводились скрещивания мягкой пшеницы (Triticum aestivum L.) с Triticum durum Desf. (5). В результате получили copта яровой мягкой пшеницы Сарроза, Саррубра, Альбосар, Блансар; сорт Саррубра был районирован в 1931 году и занимал в начале 1940-х годов около 1,3 млн га (6). Позднее для расширения регионального генетического разнообразия сортов мягкой пшеницы в условиях Поволжья привлекались виды родов Triticum - T. durum, T. dicoccum Schuebl., T. dicoccoides (Koern. ex Aschers. et Graebn) Schweinf. и Agropyron - Ag. intermedium (Host.) Beauv., Ag. elongatum (Host.) P.В., а также Secale cereale L. В результате были получены сорта Л503, Л505, Добрыня (с генетическим материалом от Ag. elongatum), Белянка (Ag. intermedium), Фаворит, Воевода (сочетание генетического материала от Ag. intermedium и сорта твердой пшеницы Краснокутка 10), Лебёдушка (присутствует генетический материала от Ag. elongatum и Ag. intermedium), Прохоровка, Юго-Восточная 2 (Secale cereale) (6).

Совершенствование генетической защиты посредством увеличения разнообразия выращиваемых высокопродуктивных сортов пшеницы с использованием доноров новых $L r$-генов или эффективным сочетанием известных $L r$-генов позволяет стабилизировать эпифитотийную ситуацию с бурой ржавчиной (2). В результате был получен перспективный селекционный материал яровой мягкой пшеницы с высокой устойчивостью к бурой ржавчине, в связи с чем крайне актуально изучение его генетического разнообразия по $L r$-генам.

Изучение генетического состава популяции патогена по признаку вирулентности составляет одну из основ опережающей селекции культур на резистентность. Оно позволяет корректировать стратегии использования новых доноров устойчивости для стабилизации фитосанитарной обстановки $(2,3)$. Исследования вирулентности $P$. triticina в Поволжье проводятся с 1970 года (7). Многолетние наблюдения показывают, что нижневолжская популяция возбудителя бурой ржавчины эволюционно активна, и ее вирулентность возрастает $(8,9)$. В первую очередь это обусловлено использованием новых генетически защищенных сортов пшеницы, а также тем, что территория Нижнего Поволжья подвергается заносу инокулюма с Северного Кавказа, из Западной Европы и Средней Азии (10).

В настоящей работе впервые рассмотрено генетическое разнообразие перспективных линий яровой мягкой пшеницы по генам устойчивости в условиях Нижнего Поволжья. Определены эффективные комбинации 
генов резистентности, линии-носители новых не идентифицированных $\mathrm{Lr}$ генов, интрогрессированных из сортов твердой пшеницы, а также состав популяции возбудителя бурой ржавчины в Саратовской области.

Цель работы - изучение генетической детерминации признака устойчивости к бурой ржавчине у новых интрогрессивных линий яровой мягкой пшеницы, выявление изменений в составе популяций возбудителя бурой ржавчины на современном этапе и определение перспективности использования имеющегося набора $L r$-линий для селекции на устойчивость к бурой ржавчине в Поволжье.

Методика. Материалом служили 42 перспективные интрогрессивные линии мягкой пшеницы, которые показали высокую устойчивость к бурой ржавчине в условиях Нижнего Поволжья в 2014-2018 годах. В качестве рекуррентных родителей при создании линий служили широко возделываемые в Нижнем Поволжье сорта яровой мягкой пшеницы Саратовская 68, Саратовская 70, Саратовская 73, Саратовская 74, Фаворит, Добрыня, Белянка, Воевода, Л503, Л505, Прохоровка. Для расширения генетического разнообразия по устойчивости к бурой ржавчине они были скрещены с носителями чужеродных эффективных генов (Lr24, Lr29, Lr36, Lr37 и др.), с устойчивыми к бурой ржавчине образцами видов $T$. durum, T. dicoccum (Schrank) Schuebl., T. persicum (Percival) Vavilov., T. timopheevii Zhuk., T. kiharae Dorof. et Migusch., Aegilops squarrosa L. (=Ae. tauschii L.) $(11,12)$ и с восприимчивым образцом T. petropavloskyi Udacz et. Migusch.

Устойчивость интрогрессивных линий к бурой ржавчине оценивали в лабораторных (в фазу проростков, 1-го листа) и полевых (в фазу молочной и молочно-восковой спелости; селекционный посев НИИ сельского хозяйства Юго-Востока - НИИСХ ЮВ, естественный инфекционный фон) условиях. В фазу проростков растения инокулировали четырьмя географически отдаленными популяциями $P$. triticina (саратовская, челябинская, краснодарская, дагестанская), собранными в 2018 году, и тремя тест-клонами, маркированными вирулентностью для носителей $\operatorname{Lr} 9, \operatorname{Lr} 19$ и $\operatorname{Lr} 26$.

Изучаемые линии пшеницы высевали в вегетационные сосуды с почвой. В фазу 1-го листа (10-14-е сут) проростки инокулировали водной суспензией спор патогена $\left(1 \times 10^{6} /\right.$ мл) с добавлением детергента Tween 80 . Зараженные растения помещали во влажную камеру в темноту на 12-14 ч, после чего переносили в камеру искусственного климата Versatille Environmental Test Chamber MLR-352H («SANYO Electric Co., Ltd», Япония) (температура $22{ }^{\circ} \mathrm{C}$, влажность $75 \%$ ). Результаты учитывали на 10-е сут по шкале E.B. Mains и H.S. Jackson (13): 0 - отсутствие симптомов, 0; некрозы без пустул, 1 - очень мелкие пустулы, окруженные некрозом, 2 пустулы среднего размера, окруженные некрозом или хлорозом, 3 - пустулы среднего размера без некроза, 4 - крупные пустулы без некроза, $\mathrm{X}$ разные типы пустул на одном листе, присутствуют хлорозы и некрозы. Растения с типом реакции 0,$0 ;, 1,2$ относили к устойчивым, 3, 4, X - к восприимчивым.

С использованием молекулярных маркеров проводили идентификацию 22 Lr-генов: Lr1 (маркер WR003) (14), Lr3 (Xmwg798) (15), Lr9 (SCS5) (16), Lr10 (Fi.2245/Lr10-6/r2) (17), Lr19 (SCS265) (18), Lr20 (STS638) (19), Lr21 (Lr21L/R) (https://maswheat.ucdavis.edu/protocols/Lr21/index.htm), Lr22a (WMS296) (20), Lr24 (Sr24\#12, Sr24\#50) (21), Lr25 (Lr25F20/R19) (https://maswheat.ucdavis.edu/protocols/Lr25/index.htm), Lr26 (SCM9) (22), Lr28 (SCS421) (23), Lr29 (Lr29F24) (24), Lr34 (csLV34) (25), Lr35 (Sr39=22) (26), Lr37 (Ventriup/LN2) (27), Lr41 (GDM35) (28), Lr47 (29), Lr50 (WMS382, GDM87) (https://maswheat.ucdavis.edu/protocols/Lr50/index.htm), Lr53 (cfd1) 
(30), Lr66 (S13-R16) (31), LrAgi (J09/1_pr1,4a) (32, 33). ДНК из растений пшеницы выделяли по методике Д.Б. Дорохова и Э. Клоке (34).

Вирулентность саратовской популяции анализировали в 2017-2018 годах. Инфекционный материал $P$. triticina был собран на селекционном посеве НИИСХ ЮВ. Размножение образцов популяций и получение монопустульных изолятов выполняли по методу лабораторного культивирования патогена (35). Вирулентность патогена и устойчивость линий к бурой ржавчине изучали на проростках пшеницы (фаза 1-го листа) согласно ранее описанной методике (36). У 35 изогенных линий Thatcher и сортов пшеницы с генами Lr1, Lr2a, Lr2b, Lr2c, Lr3a, Lr3bg, Lr3ka, Lr9, Lr10, Lr11, Lr14a, Lr14b, Lr15, Lr16, Lr17, Lr18, Lr19, Lr20, Lr21, Lr24, Lr26, Lr28, Lr29, Lr30, Lr39(=41), Lr42, Lr44, Lr45, Lr47, Lr48, Lr49, Lr51, Lr53, Lr57 и Lr6Agi оценили устойчивость к сборной саратовской популяции патогена. Расовый состав патогена и частоту вирулентности в отношении 20 линий-дифференциаторов определяли с использованием монопустульных изолятов. Фенотипы обозначали по североамериканской номенклатуре (37), основанной на определении вирулентности для групп TcLr-линий. В представленном исследовании была использована следующая последовательность ТсLr-линий (по набору $L r$-генов): 1 - Lr1, Lr2a, Lr2c, Lr3a; 2 Lr9, Lr16, Lr24, Lr26; 3 - Lr3ka, Lr11, Lr17, Lr30; 4 - Lr2b, Lr3bg, Lr14a, $L r 14 b ; 5$ - Lr15, Lr18, Lr19, Lr20. Буквенный код фенотипов и частоты вирулентности получали с использованием пакета программ Virulence Analysis Tool (VAT) (https://en-lifesci.tau.ac.il/profile/kosman/vat).

Результаты. Характеристика вирулентности используемого инфекционного материала представлена в таблице 1, список маркеров для идентификации генов устойчивости к патогену - в таблице 2.

1. Характеристика вирулентности для линий Thatcher у популяций и клонов Puccinia triticina Erikss., использованных при анализе резистентности к патогену у изучаемых интрогрессивных линий яровой мягкой пшеницы

\begin{tabular}{|c|c|c|c|}
\hline \multirow{2}{*}{$\begin{array}{l}\text { Популяции } \\
\text { и изоляты }\end{array}$} & \multirow{2}{*}{ Происхождение } & Вирулентность & Авирулентность \\
\hline & & \multicolumn{2}{|c|}{ для линий Thatcher с генами $L r$} \\
\hline Тест-клон 1 & Челябинская обл., 2017 год & $\begin{array}{l}\text { Lr1, Lr2a, Lr2b, Lr2c, Lr3a, Lr3bg, Lr3ka, } \\
\text { Lr9, Lr10, Lr11, Lr14a, Lr14b, Lr15, Lr16, } \\
\text { Lr17, Lr18, Lr20, Lr30 }\end{array}$ & $\begin{array}{l}\text { Lr19, Lr23, Lr24, Lr26, } \\
\text { Lr28, Lr29, Lr44 }\end{array}$ \\
\hline Тест-клон 2 & Тамбовская обл., 2016 год & $\begin{array}{l}\text { Lr1, Lr2a, Lr2b, Lr2c, Lr3a, Lr3bg, Lr3ka, } \\
\text { Lr10, Lr14a, Lr14b, Lr15, Lr17, Lr18, } \\
\text { Lr19, Lr20, Lr30, Lr44 }\end{array}$ & $\begin{array}{l}\operatorname{Lr} 9, \operatorname{Lr} 11, \operatorname{Lr} 16, \operatorname{Lr} 23, \\
\operatorname{Lr} 24, \operatorname{Lr} 26, \operatorname{Lr} 28, \operatorname{Lr} 29\end{array}$ \\
\hline Тест-клон 3 & $\begin{array}{l}\text { Краснодарский край, } 2017 \\
\text { год }\end{array}$ & $\begin{array}{l}\text { Lr1, Lr2a, Lr2b, Lr2c, Lr3a, Lr3bg, Lr3ka, } \\
\text { Lr10, Lr11, Lr14a, Lr14b, Lr15, Lr17, } \\
\text { Lr18, Lr20, Lr23, Lr6, Lr30, Lr44 }\end{array}$ & $\begin{array}{l}\operatorname{Lr} 9, \operatorname{Lr} 16, \operatorname{Lr} 19, \operatorname{Lr} 24, \\
\operatorname{Lr} 28, \operatorname{Lr} 29\end{array}$ \\
\hline Поп_Сар & Саратовская обл., 2018 год & $\begin{array}{l}\text { Lr1, Lr2a, Lr2b, Lr2c, Lr3a, Lr3bg, Lr3ka, } \\
\text { Lr10, Lr11, Lr14a, Lr14b, Lr15, Lr14b, } \\
\text { Lr15, Lr19, Lr20, Lr23, Lr26, Lr30 }\end{array}$ & $\begin{array}{l}\operatorname{Lr} 9, \operatorname{Lr} 24, \operatorname{Lr} 28, \operatorname{Lr} 29, \\
\operatorname{Lr} 44\end{array}$ \\
\hline Поп_Кр & $\begin{array}{l}\text { Краснодарский край, } 2018 \\
\text { год }\end{array}$ & $\begin{array}{l}\operatorname{Lr} 1, \operatorname{Lr} 2 b, \operatorname{Lr} 2 c, \operatorname{Lr} 3 a, \operatorname{Lr} 3 b g, \operatorname{Lr} 3 k a, \operatorname{Lr} 10, \\
\operatorname{Lr} 11, \operatorname{Lr} 14 a, \operatorname{Lr} 14 b, \operatorname{Lr} 16, \operatorname{Lr} 17, \operatorname{Lr} 18, \\
\operatorname{Lr} 23, \operatorname{Lr} 26, \operatorname{Lr} 30, \operatorname{Lr} 44\end{array}$ & $\begin{array}{l}\operatorname{Lr} 9, \operatorname{Lr} 2 a, \operatorname{Lr} 15, \operatorname{Lr} 19 \\
\operatorname{Lr} 20, \operatorname{Lr} 24, \operatorname{Lr} 28, \operatorname{Lr} 29\end{array}$ \\
\hline Поп_Чел & Челябинская обл., 2018 год & $\begin{array}{l}\text { Lr1, Lr2a, Lr2b, Lr2c, Lr3a, Lr3bg, Lr3ka, } \\
\text { Lr9, Lr10, Lr11, Lr14a, Lr14b, Lr15, Lr16, } \\
\text { Lr17, Lr18, Lr20, Lr30 }\end{array}$ & $\begin{array}{l}\operatorname{Lr} 19, \operatorname{Lr} 23, \operatorname{Lr} 24, \operatorname{Lr} 26, \\
\operatorname{Lr} 28, \operatorname{Lr} 29, \operatorname{Lr} 44\end{array}$ \\
\hline Поп_Даг & $\begin{array}{l}\text { Республика Дагестан, } 2018 \\
\text { год }\end{array}$ & $\begin{array}{l}\text { Lr1, Lr2a, Lr2b, Lr2c, Lr3a, Lr3bg, Lr3ka, } \\
\text { Lr10, Lr11, Lr14a, Lr14b, Lr15, Lr16, } \\
\text { Lr17, Lr18, Lr20, Lr23, Lr26, Lr30, Lr44 }\end{array}$ & $\begin{array}{l}\operatorname{Lr} 9, \operatorname{Lr} 19, \operatorname{Lr} 24, \operatorname{Lr} 28 \\
\operatorname{Lr} 29\end{array}$ \\
\hline
\end{tabular}

\section{2. ПЦР маркеры, использованные для идентификации $L r$-генов}

\begin{tabular}{|c|c|c|c|c|}
\hline Ген & Маркер & $\begin{array}{l}\text { Нуклеотидная } \\
\text { последовательность } 5^{\prime} \rightarrow 3^{\prime}\end{array}$ & $\begin{array}{l}\text { Размер, } \\
\text { П.н. }\end{array}$ & Источник \\
\hline$\overline{L r 1}$ & $\begin{array}{l}\text { WR003F } \\
\text { WR003R }\end{array}$ & $\begin{array}{l}\text { GGGACAGAGACCTTGGTGGA } \\
\text { GACGATGATGATTTGCTGCTGG }\end{array}$ & 760 & Qiu et al., 2007 \\
\hline $\operatorname{Lr} 3$ & $\begin{array}{l}\text { Xmwg798F } \\
\text { Xmwg798R }\end{array}$ & $\begin{array}{l}\text { GGCTGTCTACATCTTCTGCA } \\
\text { CAAGTGTTGAGAAGGAGAGT }\end{array}$ & 365 & Herrera-Foessel et al., 2007 \\
\hline
\end{tabular}




\begin{tabular}{|c|c|c|c|c|}
\hline \multirow[b]{2}{*}{$\operatorname{Lr} 9$} & & & \multirow[b]{2}{*}{550} & \multirow{2}{*}{$\begin{array}{l}\text { Продолжение таблицы } 2 \\
\text { Gupta et al., } 2005\end{array}$} \\
\hline & $\begin{array}{l}\text { SCS5F } \\
\text { SCS5R }\end{array}$ & $\begin{array}{l}\text { TGCGCCCTTCAAAGGAAG } \\
\text { TGCGCCCTTCTGAACTGTAT }\end{array}$ & & \\
\hline \multirow[t]{2}{*}{ Lr10 } & Fi. 2245 & GTGTAATGCATGCAGGTTCC & \multirow{2}{*}{310} & \multirow{2}{*}{ Chelkowski et al., 2008} \\
\hline & Lr10-6/r2 & AGGTGTGAGTGAGTTATGTT & & \\
\hline \multirow{2}{*}{$\operatorname{Lr} 19$} & SCS265 F & GGCGGATAAGCAGAGCAGAG & \multirow{2}{*}{512} & \multirow{2}{*}{ Gupta et al., 2006} \\
\hline & SCS265 R & GGCGGATAAGTGGGTTATGG & & \\
\hline \multirow[t]{2}{*}{ Lr20 } & STS638-L & ACAGCGATGAAGCAATGAAA & \multirow{2}{*}{542} & \multirow{2}{*}{ Neu et al., 2002} \\
\hline & STS638-R & GTCCAGTTGGTTGATGGAAT & & \\
\hline \multirow[t]{2}{*}{$\operatorname{Lr} 21$} & Lr21L & CGCTTTTACCGAGATTGGTC & \multirow{2}{*}{669} & \multirow{2}{*}{ https://maswheat.ucdavis.edu/ } \\
\hline & Lr21R & TCTGGTATCTCACGAAGCCTT & & \\
\hline \multirow[t]{2}{*}{$\operatorname{Lr} 22 a$} & WMS296F & ААТTCAАССТАССААТСТСТG & 131 & \multirow{2}{*}{ Hiebert et al., 2007} \\
\hline & WMS296R & GCCTAATAAACTGAAAACGAG & 121 & \\
\hline \multirow[t]{2}{*}{ Lr24 } & $\mathrm{Sr} 24 \mathrm{12F}$ & CACCCGTGACATGCTCGTA & \multirow[b]{2}{*}{550} & \multirow{2}{*}{ Mago et al., 2005} \\
\hline & $\mathrm{Sr} 2412 \mathrm{R}$ & AACAGGAAATGAGCAACGATGT & & \\
\hline \multirow[t]{2}{*}{ Lr25 } & Lr25F20 & CCACCCAGAGTATACCAGAG & \multirow{2}{*}{1800} & \multirow{2}{*}{ https://maswheat.ucdavis.edu/ } \\
\hline & Lr25R19 & CCACCCAGAGCTCATAGAA & & \\
\hline \multirow{2}{*}{$\operatorname{Lr} 28$} & $\mathrm{SCS} 421 \mathrm{~F}$ & ACAAGGTAAGTCTCCAACCA & \multirow{2}{*}{570} & \multirow{2}{*}{ Cherukuri et al., 2005} \\
\hline & SCS421R & AGTCGACCG AGATTTTAACC & & \\
\hline $\operatorname{Lr} 29$ & Lr29F24F & GTGACCTCAGGCAATGCACACAGT & 98, & Procunier et al 1995 \\
\hline & Lr29F24R & GTGACCTCAGAACCGATGTCCATC & 900 & Procunter el al., 1995 \\
\hline & SCM9F & TGACAACCC CCTTTCCCTCGT & 207 & Weng et al 2007 \\
\hline & SCM9R & TCATCGACGCTAAGGAGGACCC & 201 & Weng et al., 2007 \\
\hline $\operatorname{Lr} 34$ & $\operatorname{csLV} 34 \mathrm{~F}$ & GTTGGTTAAGACTGGTGATGG & & \\
\hline & csLV34F & TGCTTGCTATTGCTGAATAGT & 150 & Lagudah et al., 2006 \\
\hline Lr35 & $\mathrm{Sr} 39=22 \mathrm{~F}$ & AGAGAAGATAAGCAGTAAACATG & 800 & $\mathrm{Ma}$ \\
\hline & $\mathrm{Sr} 39=22 \mathrm{R}$ & TGCTGTCATGAGAGGAACTCTG & 800 & Mago et al., 2009 \\
\hline Lr37 & Venttriup & AGGGGCTACTGACCAAGGCT & 259 & Helopera et al 2003 \\
\hline & LN2 & TGCAGCTACAGCAGTATGTACACAAAA & 209 & Metguera ct al., 2005 \\
\hline & GDM 35F & CCTGCTCTGCCCTAGATACG & 100 & ectcos \\
\hline r41 & GDM 35R & ATGTGAATGTGATGCATGCA & 190 & Pestsova et al., 2000 \\
\hline $\operatorname{lr} 4$ & PS10F & GCTGATGACCCTGACCGG & 28 & $\mathrm{He}$ \\
\hline Lr4 & PS10R & TCTTCATGCCCGGTCGGGT & 282 & Helguera et al., 2000 \\
\hline & WMS382-F & GTCAGATAACGCCGTCCAAT & $13,2>3$ & \\
\hline$I$ & WMS382-R & CTACGTGCACCACCATTTTG & 139 & https://maswheat.ucdav- \\
\hline $\operatorname{Lr} 30$ & GDM87F & AATAATGTGGCAGACAGTCTTGG & & is.edu/protocols/Lr50/index.htm \\
\hline & GDM87R & CCAAGCCССАAТСТСТСТСТ & & \\
\hline$L r$ & $\operatorname{cfd} 1 \mathrm{~F}$ & ACCAAAGAACTTGCCTGGTG & 22 & Da \\
\hline $\operatorname{Lr} 3$ & $\operatorname{cfd} 1 \mathrm{R}$ & AAGCCTGACCTAGCCCAAAT & 22 & Dadknodale et al., 2 \\
\hline Lr66 & S13-R16F & GGTGAACGCTAAACCCAGGTAACC & 695 & Marais et al., 2010 \\
\hline & S13-R16R & CAACCTGGGAAGATGCTGAG & & \\
\hline LrAgi & $\mathrm{J} 09 / 1$ & TCTAGTCTGTACATGGGGGC & & Schachermayr et al., 1995 \\
\hline Lragl & $\operatorname{Pr} 1,4 a$ & Конфиденциальная информация & & Сибикеев с соавт., 2018 \\
\hline
\end{tabular}

Особенность саратовской селекции при создании сортов пшеницы состоит в преемственности и улучшении местного высокоадаптированного генофонда новым генетическим материалом (38). Сорта яровой мягкой пшеницы, использованные нами в качестве рекуррентного родителя, относятся к группе высокопродуктивных и широко возделываемых в Нижнем Поволжье и других регионах России (39). Они существенно различаются между собой по степени устойчивости к бурой ржавчине. Группа сортов бренда Саратовская (Саратовская 29, Саратовская 55, Саратовская 68, Саратовская 70, Саратовская 73, Саратовская 74) и сорт Прохоровка относятся к высоковосприимчивым. ПЦР-анализ показал наличие у большинства из них малоэффективного гена $\operatorname{Lr} 10$ (за исключением сортов Саратовская 55 и Саратовская 70). У сорта Прохоровка дополнительно был идентифицирован ген $\operatorname{Lr} 26$ (табл. 3).

Сорта Л503, Л505 и Добрыня защищены геном Lr19. У сортов Л503 и Л505 также был идентифицирован ген $\operatorname{Lr} 10$. Проростки и взрослые растения этих сортов показывали устойчивость к популяциям патогена, авирулентным в отношении линий и сортов с $\operatorname{Lr} 19$, и восприимчивость - к вирулентным (см. табл. 3). Степень их поражения в полевых условиях Нижнего Поволжья варьировала от 0 до 20 \%, что было обусловлено разной представленностью изолятов, вирулентных для растений с геном $\operatorname{Lr19}$, так как площади под сортами - носителями этого гена устойчиво- 
3. Устойчивость интрогрессивных линий яровой мягкой пшеницы, созданных в НИИ сельского хозяйства Юго-Востока, к бурой ржавчине и идентифицированные у них $\boldsymbol{L r}$-гены (экспериментальное поле НИИСХ ЮВ, г. Саратов, 2016-2018 годы)

\begin{tabular}{|c|c|c|c|c|c|c|c|c|c|c|c|}
\hline \multirow{2}{*}{ Линия } & \multirow{2}{*}{ Родословная } & \multirow{2}{*}{$\mathrm{B} \Gamma$} & \multirow{2}{*}{$\begin{array}{l}\text { ППН, \%/тип } \\
\text { реакции, балл }\end{array}$} & \multicolumn{7}{|c|}{ Тип реакции в фазу проростков, балл } & \multirow{2}{*}{$L r$-гены } \\
\hline & & & & 1 & 2 & 3 & 4 & 5 & 6 & 7 & \\
\hline & & & I группа & & & & & & & & \\
\hline л3 & Milan/Prinia*4//Добр/3/Фав & Aegilops ventricosa & $0 / 0$ & 0 & 0 & 0 & 0 & 0 & 0 & 0 & $L r 19+\operatorname{Lr} 37+\operatorname{Lr} 6 A g i$ \\
\hline Л42 & Добр/Trident//Добр/3/Добр/4/Добр & Aegilops ventricosa & $0 / 0$ & 0 & 0 & $2-$ & 0 & 3 & 0 & $1-2$ & $\operatorname{Lr} 19+\operatorname{Lr} 37$ \\
\hline Л10 & Л164/Прох//Л164/Добр Lr9 & Ae. umbellulata & $0 / 0$ & 0 & 0 & 0 & 0 & 0 & 0 & 0 & $\operatorname{Lr} 19+\operatorname{Lr} 26$ \\
\hline Л4 & Добр*2//Л2033/Бел/3/Добр Lr24 & Ag. elongatum & $0 / 0$ & 0 & 0 & 0 & 0 & 0 & 0 & 0 & $\operatorname{Lr} 19+\operatorname{Lr6Agi}$ \\
\hline Л52 & $\mathrm{C} 70 / \mathrm{Tc} L r 29 * 4 / / \mathrm{C} 70$ & Ag. elongatum & $0-2 / 0 ;$ и 1 & 0 & 0 & 0 & 0 & 0 & 0 & 0 & $\operatorname{Lr} 29$ \\
\hline \multirow[t]{2}{*}{ Л30 } & Л503 ТсLr36//Л503/3/Л503 & Ae. speltoides & $0-2 / 1$ & 0 & 3 & $0-1$ & 0 & 0 & 0 & $0-1$ & $\operatorname{Lr} 10+\operatorname{Lr} 19$ \\
\hline & Л164/Can 30п//C68 & Triticum durum & II гру п п а & 0 & 0 & 0 & 0 & 0 & 0 & 0 & $I r 19+\operatorname{IrTdur}$ \\
\hline Л 25 & С58*2//Зол. волна/3/C68 & Triticum durum & $0 / 0$ & 0 & 0 & 0 & 0 & 0 & 0 & 0 & Lr10 + Lr19+ LrTdur \\
\hline Л39 & Добр/Зол. волна//Добр/3/Добр & Triticum durum & $0 / 0$ & 0 & $0-1$ & 0 & 0 & 0 & 0 & 0 & Lr19+ LrTdur \\
\hline Л43 & Добр*4/Ник & Triticum durum & $0 / 0$ & 0 & 3 & 0 & 0 & 0 & 0 & 0 & $\operatorname{Lr} 19$ \\
\hline Л13 & Добр*3//Ник & Triticum durum & $0 / 0$ & 0 & 0 & 0 & 0 & 0 & 0 & 0 & $\operatorname{Lr} 19+\operatorname{Lr} 26$ \\
\hline Л19 & Добр*4/Ник/Грекум С2193 Л1314/2 16 & Triticum durum & $0-5 / 0$; и 3 & 0 & 0 & 0 & 0 & 0 & 0 & 0 & Lr10 + Lr19+ LrTdur \\
\hline л2 & Л505/Л164/4/Л503//Trap\# 1/Bow/3/Л503/5/Л505/6/Ал32 & Triticum durum & $0 / 0$ & 0 & 0 & $0-1$ & 0 & 0 & 0 & 0 & $\operatorname{Lr} 10+\operatorname{Lr} 19+\operatorname{Lr} 26$ \\
\hline Л11 & Л505/Л164//Прох & Triticum durum & $0 / 0$ & 0 & $0-1$ & 0 & 0 & 0 & 0 & 0 & Lr10 + Lr19+ LrTdur \\
\hline Л46 & Прох/Л164//Прох/3/Л164/4/Л164 & Triticum durum & $0 / 0$ & 0 & 0 & 0 & 0 & 0 & 0 & 0 & $\operatorname{Lr} 19+\operatorname{Lr} 26$ \\
\hline л38 & Добр/T. persicum//Добр & T. persicum & $0 / 0$ & 0 & $0-1$ & 0 & 0 & 0 & 0 & 0 & Lr19+ LrTpers \\
\hline Л24 & $\mathrm{C} 74 / T$. dicoccum $\mathrm{k} 7507 / / \mathrm{C} 73$ & T. dicoccum & $0 / 0$ & 0 & 0 & 0 & 0 & 0 & 0 & 0 & $\operatorname{Lr} 19+\operatorname{Lr} 26$ \\
\hline Л 28 & С74/T. dicoсcum $\mathrm{k} 7507 / / \mathrm{C} 73 / 3 / \mathrm{C} 73$ Л1504/2 16 & T. dicoccum & $0-5 / 0$ и 3 & 0 & 0 & $1-2$ & 0 & 0 & 0 & $0-1-2$ & $\operatorname{Lr} 10+\operatorname{Lr} 19+\operatorname{Lr} 26$ \\
\hline л29 & C74/T. dicoccum $\mathrm{k} 7507 / / \mathrm{C} 73 / 3 / \mathrm{C} 73$ & T. dicoccum & $0 / 0$ & 0 & $0-1$ & 0 & 0 & 0 & 0 & $0-1$ & $\operatorname{Lr} 10+\operatorname{Lr} 19+\operatorname{Lr} 26$ \\
\hline Л47 & $\mathrm{C} 74 /$ T. dicoccum $\mathrm{k} 7507 / / \mathrm{C} 73 / 3 / \mathrm{C} 73$ & T. dicoccum & $0 / 0$ & 0 & 0 & 3 & 0 & $0-2$ & 0 & 3 & $\operatorname{Lr} 10+\operatorname{Lr} 26$ \\
\hline Л48 & C74/T. dicoccum $\mathrm{k} 7507 / / \mathrm{C} 73 / 3 / \mathrm{C} 73$ & T. dicoccum & $0 / 0$ & 0 & 0 & 0 & 0 & 0 & 0 & 0 & $\operatorname{Lr} 19+\operatorname{Lr} 26$ \\
\hline Л5 & C55*5/T. dicoccoides// Добр Lr9 & T. dicoccoides + Lr9 & $0 / 0$ & 0 & 0 & 0 & 0 & 0 & 0 & 0 & $\operatorname{Lr} 19+\operatorname{Lr} 26$ \\
\hline \multirow[t]{2}{*}{ Л49 } & С68/T. timopheevil*4//Добр & T. timopheevii & $0 / 0$ & 0 & 0 & 0 & 0 & 0 & 0 & 0 & Lr10 + Lr28=LrTtim? \\
\hline & & & III группа & & & & & & & & \\
\hline Л6 & Croc/Ae. squarrosa (205)//Weaver/3/*3 Л505 & Ae. tauschiil $(=$ Ae. squarrosa $)$ & $0 / 0$ & 0 & 0 & 0 & 0 & 0 & 0 & 0 & Lr19 + LrAtau? \\
\hline Л7 & Бел/3/Croc/Ae. squarrosa (205)//Weaver/4/Бел & Ae. tauschii $(=A e$. squarrosa $)$ & $0 / 0$ & 0 & 0 & 0 & 0 & 0 & 0 & 0 & $L r 10+L r 26+L r 6 A g i$ \\
\hline л9 & Croc/Ae. squarrosa//Weaver/3/*3 Л505 & Ae. tauschii $(=A e$. squarrosa $)$ & $0 / 0$ & 0 & 0 & 0 & 0 & 0 & 0 & 0 & $\operatorname{Lr} 19+\operatorname{Lr} 26$ \\
\hline л20 & Croc/Ae. squarrosa (205)//Weaver/3/Л505/4/Бел/5/Фав/6/С74 & 4 Ae. tauschï $(=$ Ae. squarrosa $)$ & $0 / 0$ & 0 & 0 & 0 & 0 & 0 & 0 & 0 & $\operatorname{Lr} 10+\operatorname{Lr} 6 A g i$ \\
\hline Л40 & Добр/3/Croc/Ae. squarrosa (205)//Weaver/4/Добр & Ae. tauschï $(=$ Ae. squarrosa $)$ & $0 / 0$ & 0 & 0 & 0 & 0 & 0 & 0 & 0 & $\operatorname{Lr} 10+\operatorname{Lr} 39+\operatorname{Lr} 6 A g i$ \\
\hline Л44 & Л505/3/Croc/Ae. squarrosa (205)//Weaver/4/Л505/5/С68 & Ae. tauschï $(=$ Ae. squarrosa $)$ & $0 / 0$ & 0 & 0 & 0 & 0 & 0 & 0 & 0 & $\operatorname{Lr} 19+\operatorname{Lr} 26+\operatorname{Lr} 39$ \\
\hline
\end{tabular}


Добр/3/Croc/Ae. squarrosa (205)//Weaver/4/Добр/5/Добр $\quad$ Ae. tauschï(=Ae. squarrosa) Croc/Ae. squarrosa (205)//Weaver/3/Л505/4/Бел/5/Фав/6/ФавAe. tauschïl(=Ae. squarrosa)

Л21 Воев/T. petropavloskyi//Воев

Л31 Воев/T. petropavloskyi*3//Воев

С70/T. kiharae//Добр/3/Добр

С68/T. kiharae//Л503

C68/T. kiharae//C70/3/C68/4/C68

C68/T. kiharae//C70/3/C70/4/C70

С68/T. kiharae//Добр/3/Добр

С68/T. kiharae//Добр/3/Добр/4/Добр

Виктория 95/№ 1

Виктория 95/№

Виктория 95/№

T. petropavloskyi

T. petropavloskyi

$50 / 3$
$0 / 0 ;$
$\mathrm{V}$ гр у п п а
$15 / 1$ и 3
$0 / 0 ;$
$0 / 0 ;$
$0 / 0 ;$
$0 / 0 ;$
$0 / 0 ;$
$0 / 0 ;$
$0-5 / 0 ;$ и 1
$0-20 / 0 ;$ и 3

\section{T. kiharae}

T. kiharae

T. kiharae

T. kiharae
T. kiharae

T. kiharae

T. miguschovae

T. miguschovae

T. miguschovae

$0-20 / 0$; и 3

Сорта яровой мягкой пшениц

$70 / 3-4$
$70 / 3-4$

Саратовская 55

Саратовская 68

Саратовская 73

Саратовская 74

Фаворит

Воевода

Белянка

Добрыня

Л503

$\begin{array}{lc} & 70 / 3-4 \\ & 70 / 3-4 \\ & 40 / 3 \\ & 70 / 3-4 \\ & 50 / 3 \\ & 60 / 3 \\ \text { Agropyron intermedium } & 0 / 0 ; \\ \text { Ag. intermedium } & 0 / 0 ; \\ \text { Ag. intermedium } & 0 / 0 ; \\ \text { Ag. elongatum } & 15 / 2-3 \\ \text { Ag. } \text { elongatum } & 15 / 2-3 \\ \text { Ag. elongatum } & 15 / 2-3 \\ \text { Secleste } & 30 / 3\end{array}$

Ag. elongatum

Прохоровка

0/3-4

$50 / 3$

$0 / 0$

$0 / 0$

$0 / 0$

$30 / 3$

П р и м е ч а н и е. ВГ - виды, используемые в гибридизашии, ППУ - пораженность в полевых условиях; популящии и изоляты: $1-$ Тест-клон $1,2-$ Тест-клон $2,3-$ Тест-клон $3,4-$

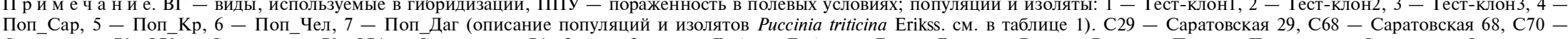

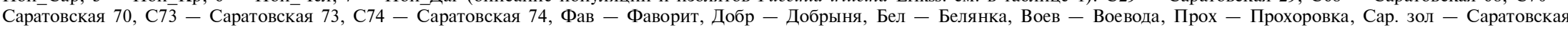

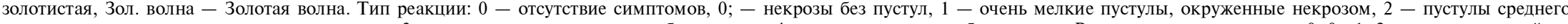

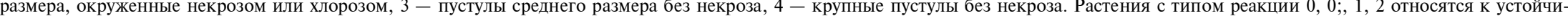
вым, 3, 4 - к восприимчивым (13). Прочерки в таблице означают, что соответствующие образцы не анализировали. 
сти сокращются. В России первые сорта с геном Lr19 стали возделывать с конца 1980-х годов в Поволжье. Когда их посевные площади в середине 1990-х годов превысили 100 тыс. га, защитный эффект Lr19 был преодолен (4). В настоящее время вирулентность в отношении носителей этого гена регистрируется как в регионах возделывания сортов с $\operatorname{Lr} 19$, так и за их пределами (40, 41).

Сорта Белянка, Воевода, Фаворит - носители гена Lr6Agi, переданного от пырея промежуточного и не идентичного включенным в каталог генных символов. Эти сорта характеризуются высокой ювенильной устойчивостью в течение длительного периода их районирования (32).

К настоящему времени во всем мире идентифицировано $77 \mathrm{Lr}$ генов и свыше $50 \%$ из них относятся к чужеродными (42). Их источники виды Ae. tauschii $(\operatorname{Lr} 21(=L r 40), L r 22 a, L r 32, L r 39(=L r 41))$, Ae. umbellulata (Lr9, Lr76), Ae. speltoides (Lr28, Lr35, Lr36, Lr47, Lr51, Lr66), Ae. ventricosa (Lr37), Ae. kotschyi (Lr54), Ae. sharonensis (Lr56), Ae. geneculata (Lr57), Ae. triuncialis (Lr58), Ae. peregrina (Lr59), Ae. neglecta (Lr62), T. spelta (Lr44, Lr71), S. cereale (Lr25, Lr26, Lr45), T. timopheevii (Lr18, Lr50), Ag. elongatum (Lr19, Lr24, Lr29), Ag. intermedium (Lr38), T. dicoccoides (Lr33, Lr53, Lr64), T. durum $(L r 23, L r 61)$ и $T$. mопососcum (Lr63). В коммерческие сорта мягкой пшеницы переданы гены Lr9, Lr19, Lr21, Lr23, Lr24, Lr26, Lr28, Lr37 и Lr39 (43, 44). Некоторые из этих образцов (линии Thatcher с генами Lr9, Lr24, Lr36; copта Trident, Milan c Lr37) были использованы в наших исследованиях для расширения генетического разнообразия высокопродуктивных сортов яровой мягкой пшеницы, выращиваемых в Нижнем Поволжье. Наряду с известными $L r$-генами были использованы образцы чужеродных видов, предположительно несущие новые гены устойчивости $(10,11)$.

Гр уппа линий І. Линии Л3 и Л42 (Lr37), Л52 (Lr29), Л4 (Lr24), Л10 (Lr9) и Л30(Lr36) получены с привлечением доноров известных $L r$ генов (см. табл. 3). С использованием молекулярных маркеров наличие гена устойчивости взрослых растений Lr37 было подтверждено у линий Л3 и Л42, созданных с участием сортов Milan и Trident - доноров этого гена. Также у этих линий идентифицировали ген $\operatorname{Lr} 19$, перенесенный от сорта Добрыня, а у Л3 - дополнительный ген Lr6Agi от сорта Фаворит. Обе линии характеризовались высокой устойчивостью в полевых условиях Саратовской области. В фазу проростков тип реакции у линии Л3, несущей три гена $L r 19+\operatorname{Lr37}+\operatorname{Lr6Agi}$, был существенно выше (балл 0), чем у линии Л42 $(\operatorname{Lr} 19+\operatorname{Lr} 37)$ с восприимчивым типом реакции при инокуляции клоном № 2, вирулентным относительно $\operatorname{Lr} 19$ (см. табл. 3), и умеренно устойчивый (балл 1-2) при инокуляции дагестанской популяцией и клоном № 3, вирулентным по отношению к Lr26.

У линии Л52, полученной на основе восприимчивого к бурой ржавчине сорта Саратовская 70 и линии TcLr29, был идентифицирован только ген $\operatorname{Lr29}$. Линия Л52, как и исходная изогенная линия TcLr29, в фазу проростков оказалась высокоустойчива ко всем географическим популяциям и клонам возбудителя (тип реакции 0). В полевых условиях их тип реакции варьировал от 0; до 1. До настоящего времени $\operatorname{Lr29}$, источником которого служит Ag. elongatum, в российской и зарубежной селекции не использовали $(12,42)$.

У линий Л4 и Л10, в создании которых участвовали линии Tc $L r 24$ и TcLr9, этих генов мы не выявили. С помощью молекулярного анализа у них был определен $\operatorname{Lr} 19$, унаследованный от сорта Добрыня и Л503. У линии Л10 обнаружился дополнительный ген Lr26, переданный от сорта Прохоровка, у Л4 - Lr6Agi от сорта Белянка. Высокая устойчивость Л4 и 
Л10 в фазу проростков и взрослых растений указывает на эффективность сочетания генов Lr19+ Lr26 и Lr19+ Lr6Agi при защите от бурой ржавчины в условиях Поволжья.

Линия Л30, созданная с участием TcLr36, показала восприимчивый тип реакции в фазу проростков при заражении тест-клоном № 2, вирулентным для носителей $\operatorname{Lr} 19$. С использованием молекулярных маркеров у нее идентифицировали гены $\operatorname{Lr} 19+\operatorname{Lr} 10$. В полевых условиях у Л30 тип реакции составлял 1 балл и был ниже, чем у TcLr19, но выше, чем у TcLr36, что может быть обусловлено аддитивным взаимодействием генов $\operatorname{Lr} 10, \operatorname{Lr} 19$ и $\operatorname{Lr} 36$.

Группа линий II. Считается, что тетраплоидные виды пшеницы характеризуются более высокой устойчивостью к бурой ржавчине, чем диплоидные и гексаплоидные (45). При этом лишь несколько $L r$-генов перенесено от них в мягкую пшеницу. Наиболее представлен из них Lr23, интродуцированный от T. durum (12). Ген Lr23 потерял свою эффективность в Поволжье в конце 1990-х годов. Однако сорта мягкой пшеницы с эти геном в полевых условиях характеризуются разным остаточным эффектом устойчивости. Сорта твердой пшеницы Саратовская золотистая, Золотая волна, Ник, использованные при создании Л8, Л25, Л13, Л19, Л39 и Л43, в условиях Нижнего Поволжья обладают устойчивостью к бурой ржавчине (46). Генетический контроль их устойчивости к этой болезни неизвестен. Однако в родословных сортов Золотая волна и Ник присутствует сорт Саратовская золотистая с типом реакции на возбудителя листовой ржавчины $1,1+$.

В нашем исследовании большинство интрогрессивных линий, созданных с участием сортов твердой пшеницы, характеризовались высокой устойчивостью в фазу проростков и взрослых растений. Исключение составила линия Л43, которая оказалась поражена клоном патогена № 2, вирулентным относительно $\operatorname{Lr} 19$. Для Л8 и Л19 отмечали расщепление по устойчивости к болезни в полевых условиях, что указывает на гетерогенность этих линий и необходимость проведения дальнейших отборов.

У всех линий, полученных на основе сорта Добрыня (Л13, Л39, Л43, Л19) и сортов T. durum Золотая волна и Ник, выявили ген Lr19 (см. табл. 3). У Л13 был также определен ген Lr26, сочетание которого с Lr19 может обусловливать высокую устойчивость этой линии. У Л19 идентифицировали малоэффективный ген Lr10. У Л25 также был обнаружен ген Lr19, при этом его доноры в родословной отсутствовали. Кроме того, у этой линии выявили ген $\operatorname{Lr} 10$, источником которого был сорт Саратовская 68. Высокая степень устойчивости в фазу проростков и взрослых растений у линий Л39, Л19 и Л25 указывает на наличие дополнительного генетического материала от $T$. durum наряду с транслокацией от Ag. elongatum.

Линии Л2, Л8, Л11 и Л46 получили с участием Л164 = Л504/Caратовская 57//Л504. Генетический материал твердой пшеницы у них мог быть передан от Л164, в родословной которой имеется сорт Саратовская 57 , устойчивый к бурой ржавчине. У всех линий этой группы выявили $\operatorname{Lr} 19$, что согласуется с анализом родословной для Л2 и Л11, при создании которых использовалась линия Л505. У Л11 и Л2 идентифицировали Lr10. Ген Lr26 от сорта Прохоровка линия Л11 не унаследовала. Ее высокая устойчивость в фазу проростков и взрослых растений предполагает наличие дополнительного $L r$-гена от сорта твердой пшеницы Саратовская 57. У Л2 был определен ген Lr26 от линии Trap\#1/Bow, полученной из CIMMYT (International Maize and Wheat Improvement Center).

Сочетание трех генов $L r 10+\operatorname{Lr} 19+\operatorname{Lr} 26$ у линии Л2 обусловливает 
высокую ювенильную и взрослую устойчивость к бурой ржавчине. Как уже отмечалось, у Л8 и Л46 был идентифицирован ген $L r 19$, но его происхождение, исходя из родословных, не ясно. Тем не менее у Л46, согласно родословной, возможно наличие $\operatorname{Lr} 26$ от сорта Прохоровка, что и подтвердилось при молекулярном анализе. Следовательно, Л46 несет комбинацию Lr19 + Lr26. У Л8 наблюдалась высокая устойчивость ко всем образцам листовой ржавчины, что не может быть обусловлено наличием только $\operatorname{Lr} 19$, поэтому есть основание предположить у нее дополнительные гены от твердой пшеницы (LrTdur) сортов Золотая волна и Саратовская 57 (имеет в родословной Л164). Ранее у Л164 идентифицированы два рецессивных гена устойчивости к бурой ржавчине, переданных от сорта твердой пшеницы Саратовская 57 (47).

Наряду с твердой пшеницей, для расширения генетического разнообразия саратовских сортов яровой пшеницы были использованы образцы сходных по геномному составу $\left(A^{u} A^{u} B B\right)$ тетраплоидных видов $T$. persicum, $T$. dicoccoides, T. dicoccum, а также T. timopheevii $\left(G G A^{t} A^{t}\right)$. У линии Л38, созданной на основе сорта Добрыня и образца T. persicum, с использованием ДНК маркеров установили наличие одного гена Lr 19. При этом она характеризовалась высокой устойчивостью на протяжении всего вегетационного сезона, что указывает на присутствие дополнительного $L r$-гена от $T$. persicum. В каталоге генных символов (42) нет информации о генах, перенесенных в мягкую пшеницу от этого вида, поэтому можно предположить наличие у линии Л38 нового $L r$-гена, который в сочетании с $L r 19$ обеспечивает высокую степень защиты от бурой ржавчины.

У большинства линий (Л24, Л28, Л29, Л47, Л48), созданных на основе восприимчивых сортов Саратовская 74 и Саратовская 73 и образца T. dicoccum к-7507 (Иран), выявляли сочетание генов Lr19 и Lr26. Аналогичное сочетание было идентифицировано у линии Л5, полученной с участием T. dicoccoides. Линия Л28 гетерогенна по Lr19, что, вероятно, и обусловило ее расщепление по устойчивости к бурой ржавчине в полевых условиях. У Л28 и Л29 был также определен ген $\operatorname{Lr} 10$. Линия Л47 отличалась от них восприимчивостью к тест-клону № 3, вирулентному для образцов с Lr26. С использованием молекулярных маркеров у этой линии выявили сочетание двух малоэффективных генов Lr10 + Lr26. При этом она, как и другие линии с участием $T$. dicoccum, характеризовалась высокой устойчивостью в полевых условиях, что указывает на наличие дополнительных $L r$-генов. Ранее было показано, что устойчивость к бурой ржавчине у образца к-7507 $T$. dicoccum контролируется одним доминантным $L r$-геном (10). Причина наличия у этого материала генов от пырея удлиненного (Lr19) и ржи посевной (Lr26) неясна, однако сочетание $L r$ генов может обусловливать высокую степень устойчивости.

В каталоге генных символов (42) описаны два гена, переданных мягкой пшенице от $T$. dicoccum, - Lr53 и Lr64. Линия с Lr53 в наших многолетних исследованиях характеризовалась высокой ювенильной устойчивостью ко всем российским популяциям $P$. triticina, в том числе к саратовской (балл 0,$0 ;, 1)$. При использовании маркера cfd1 у положительного контроля с геном Lr53 амплифицировались 2 аллеля (320 и 375 п.н.) (рис. 1), а у линий Л5, Л24, Л29, Л47 и Л48 - один аллель (275 п.н.), что указывает на отсутствие у них гена $\operatorname{Lr} 53$ (29).

Линия Л49 получили с использованием T. timopheevii и сортов мягкой пшеницы Саратовская 68 ( Lr10) и Добрыня (Lr19). В результате молекулярного анализа у нее были найдены гены Lr10 и Lr28. Ген Lr19 от сорта Добрыня не выявили. Обнаружение маркера гена SCS421, по нашему 
мнению, указывает на наличие у образца генетического материала $T$. $t i$ mopheevii (LrTtim). Ранее мы показали (48), что этот маркер не строго специфичен для определения гена Lr28, переданного от Ae. speltoides, и присутствует также у образцов $T$. timopheevii.

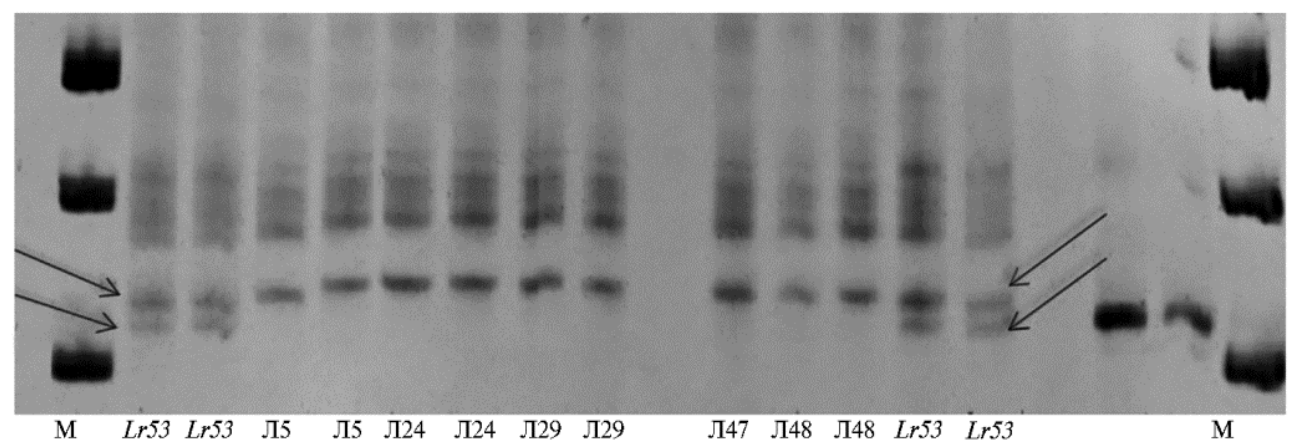

Рис. 1. ПЦР-идентификация маркера cfd1 гена $\operatorname{Lr} 53$ у интрогрессивных линий (Л) яровой мягкой пшеницы, созданных в НИИ сельского хозяйства Юго-Востока: М - маркер молекулярных масс (Маркер длин ДНК, 50 п.н., «Диаэм», Россия), Lr53 - положительный контроль (линия TcLr53). Стрелками отмечены продукты амплификации размером 320 п.н. и 375 п.н.

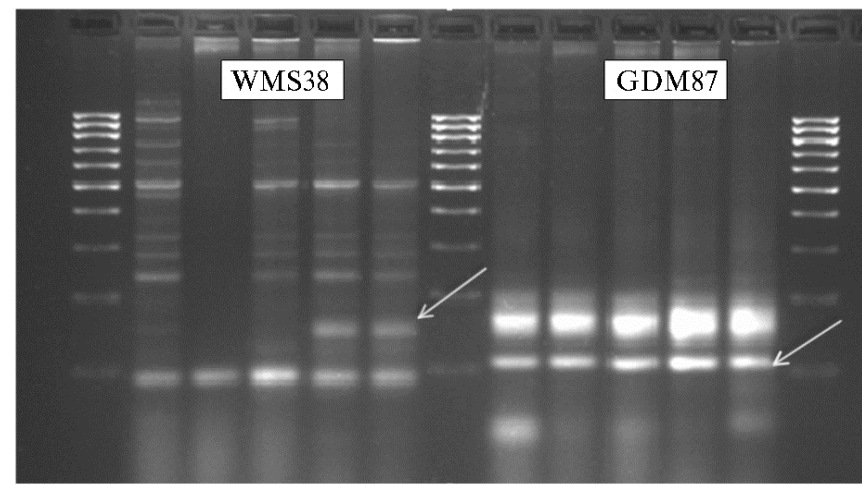

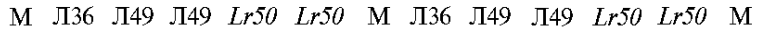

Рис. 2. ПЦР-идентификация микросателлитных маркеров WMS382 и GDM87 гена Lr50 у интрогрессивных линий (Л) яровой мягкой пшеницы, созданных в НИИ сельского хозяйства Юго-Востока: М - маркер молекулярных масс (Маркер длин ДНК, 100 п.н. «Диаэм», Россия), Lr50 - положительный контроль (линия KS96WGRC36). Стрелками отмечены продукты амплификации размером 139 п.н. (маркер WMS382) и 110 п.н. (GDM87).

Маркер WMS382 гена Lr50 более тесно сцеплен с этим геном (6,7 cM), чем GDM87 (9,4 cM). Полученный нами электрофоретический профиль указывал на отсутствие $L r 50$ у этой линии (рис. 2). Результаты с маркером GDM87, который выявляли у линии Л49 и дополнительно включенной в анализ линии Л36, оказались ложноположительными. Подобные случаи неэффективности использования этого маркера для скрининга гена Lr50 широко обсуждаются в литературе (https://maswheat.ucdavis.edu/protocols/Lr50/index.htm), в связи с чем он рекомендуется к использованию в маркер-вспомогательной селекции (MAC, marker-assisted selection, MAS) как дополнительный к WMS382.

Группа линий III. Диплоидный вид Ae. tauschii широко используется для переноса устойчивости к болезням и других хозяйственно ценных признаков во всем мире. В нашей работе для создания линий Л6, 
Л7, Л9, Л20, Л40, Л44, Л45 и Л51 привлекался синтетический амфидиплоид Croc/Ae. squarrosa (205)//Weaver, полученный в CIMMYТ; он обладает комплексом хозяйственно ценных признаков и включен в селекционный процесс во многих странах $(49,50)$. У этой группы линий не было генов Lr21 и Lr22a, переданных от Ae. taushcii, но у линий Л40, Л44 и Л45 обнаружен $\operatorname{Lr39}(=\operatorname{Lr} 41)$ (рис. 3). Ген $\operatorname{Lr} 19$ был унаследован линиями Л6, Л9, Л44, Л45 и отсутствовал у Л20, Л40 и Л51, несмотря на то, что в родословных каждой из них присутствовали сорта с этим геном. Ген Lr6Agi был определен у линий Л7 и Л20, созданных с участием сортов Фаворит и Белянка, а также у Л40 и Л45, в родословной которых указанные сорта отсутствовали.

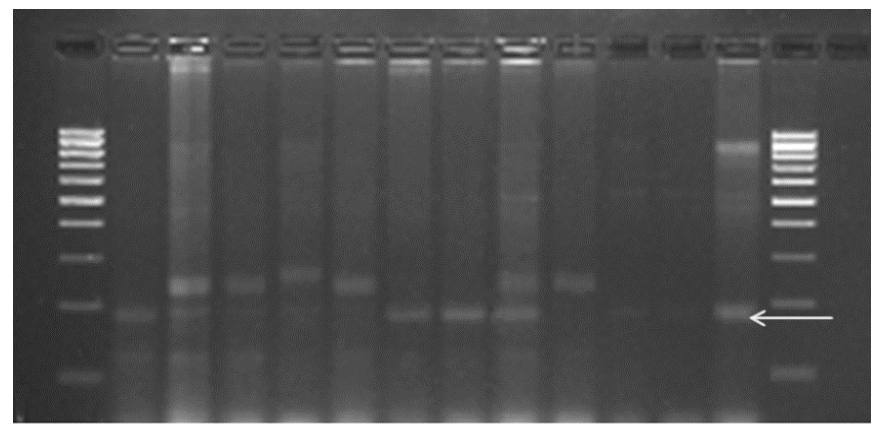

М Л1 Л6 Л7 Л9 Л20 Л40 Л44 Л55 Л51 Lr41 Lr41 Lr41 М

Рис. 3. ПЦР-идентификация микросателлитныого маркера GDM35 гена $\operatorname{Lr39}(=\operatorname{Lr} 41)$ у интрогрессивных линий (Л) яровой мягкой пшеницы, созданных в НИИ сельского хозяйства Юго-Востока: М - маркер молекулярной массы (Маркер длин ДНК, 100 п.н., «Диаэм», Россия), Lr41 - положительный контроль (линия KS-90-WGRC-10). Стрелкой отмечен продукт амплификации размером 180 п.н.
При анализе линии Л40 по растениям (выделение ДНК не из нескольких растений, а из каждого), выявили расщепление по гену Lr6Agi, а для Л45 стабильность. Для окончательного подтверждения наличия этого гена необходимо провести дополнительные цитогенетические анализы или молекулярный анализ с использованием маркеров PLUG (PCR-based landmark unique gene) $(51,52) . \mathrm{y}$

линий Л7, Л9 и Л44 идентифицировали дополнительный ген Lr26, вероятным источником которого была линия Weaver, входящая в родословную синтетика.

Все линии, созданные с использованием синтетического амфидиплоида, характеризовались высокой устойчивостью. Для Л9 $(L r 19+L r 26)$, Л44 $($ Lr19 + Lr26 + Lr39), Л7 (Lr10 + Lr26+Lr6Agi $)$, Л20 $($ Lr10 + Lr6Agi $)$, Л40 $($ Lr10 + Lr39 + Lr6Agi), Л45 (Lr10 + Lr19 + Lr39 + Lr6Agi) и Л51 (Lr6Agi) это согласуется с полученными данными по их генетическому контролю. У Л6 можно предположить наличие еще одного гена, поскольку при инокуляции клоном № 2, вирулентным для носителей Lr19, наблюдали реакцию устойчивости (см. табл. 1).

Группа лини й IV. Линии Л21 и Л31 были получены с участием восприимчивого образца гексаплоидного вида $T$. petropavloskyi и устойчивого сорта Воевода. Линия Л 21 характеризовалась восприимчивостью в фазу проростков и взрослых растений, что указывает на отсутствие у нее генетического материала от сорта Воевода. Это подтверждает и молекулярный анализ. У Л21 не были выявлены маркеры гена Lr6Agi, но обнаружен малоэффективный ген Lr10. У высокоустойчивой линии Л31 выявили ген Lr6Agi, который, вероятно, и обусловливает ее устойчивость.

В целом вид $T$. petropavloskyi характеризуется как высоковосприимчивый к грибным болезням (45). Однако он представляет интерес для селекции в качестве донора других хозяйственно-биологических признаков. Для оценки наличия генетического материала $T$. petropavloskyi у линий указанной группы необходим цитологический анализ. 
Группа линий V. Линии, включенные в эту группу, были созданы с участием гексаплоидных видов T. kiharae и T. miguschovae. T. kiharae - гомолог T. spelta L., a T. miguschovae создавался как гомолог T. aestivum. Эти виды имеют значимость для селекции мягкой пшеницы как доноры высокой продуктивности (53). Используемый при создании линий Л17, Л18, Л22, Л32, Л33 и Л53 образец T. kiharae характеризовался устойчивостью к бурой ржавчине и в предварительных исследованиях у него был выявлен один доминантный ген (12).

У всех линий этой группы обнаружен ген $\operatorname{Lr} 19$ по отдельности (Л17, Л32) или в сочетании с другими генами (Л18 - Lr19+ Lr28; Л22 $L r 10+L r 19 ;$ Л33 - Lr3 + Lr19+ Lr28; Л53 - Lr3 + Lr19). Для линий Л17, Л22 и Л32 эти результаты подтверждены фитопатологическим тестом (восприимчивость к клону № 2). Согласно родословной линий Л17, Л18, Л33, Л53, источником Lr19 у них могли быть сорта Добрыня и Л503, при этом Л22 и Л32 созданы на основе сортов Саратовская 68 и Саратовская 70, у которых этот ген отсутствует.

У линий Л18 и Л33 имелся маркер SCS421, сцепленный с Lr28 (22). Как было показано выше, он не строго специфичен для гена Lr28, переданного от Ae. speltoides, и выявляется у образцов, полученных с участием T. timopheevii (48). Гипотетически можно предположить, что проявление указанного маркера у Л18 и Л33 указывает на наличие у них генетического материала T. kiharae. Подтверждением этому служит высокая степень устойчивости к болезни в полевых и лабораторных условиях. Поскольку среди известных $L r$-генов отсутствуют переданные от этого вида (42), можно предположить, что они являются новыми и не идентичными известным эффективным $(L r T k h)$.

У линий Л56, Л57, Л58, полученных с участием T. miguschovae, тип устойчивости варьировал при заражении популяциями и клонами в фазу проростков. В фазу взрослых растений высокой устойчивостью обладала линия Л56, а у двух других отмечали расщепление по устойчивости. С использованием молекулярного маркера у Л56 и Л57 были выявлены неэффективные гены Lr3 и Lr1 и ген частичной устойчивости Lr34 (partial resistance gene). При этом у сходной по происхождению линии Л58 этих генов не обнаружили.

Анализ 42 перспективных линий пшеницы показал высокое генетическое разнообразие по устойчивости к бурой ржавчине. Среди них присутствовали носители известных $L r$-генов, ранее не использованных в селекции яровой пшеницы в России (Л4 - Lr29), и носители предположительно новых Lr-генов, переданных от T. durum (Л8, Л39 - Lr19+LrTdur, Л25, Л19, Л11 - Lr10 + Lr19 + LrTdur), T. persicum (Л38 - Lr19+ LrTpers), T. timopheevii (Л49 - Lr10 + LrTtim), Ae. tauschii (Л6 - Lr19+LrAtau), T. kiharae (Л33 - Lr3 + Lr19+LrTkh). Кроме того, нами идентифицированы носители эффективных сочетаний $L r$-генов: $\operatorname{Lr} 19+\operatorname{Lr} 26$ (Л10, Л13, Л46, Л24, Л48, Л5, Л9), Lr19 + Lr37 (Л42), Lr10 + Lr19 + Lr26 (Л2, Л28, Л29), Lr19 + Lr26 + Lr39 (Л44), Lr19 + Lr37 + Lr6Agi (Л3), Lr19 + Lr6Agi (Л4), Lr10 + Lr26 + Lr6Agi (Л7), Lr10 + Lr39 + Lr6Agi (Л40), а также Lr10 + Lr19 + Lr39 + Lr6Agi (Л45) и Lr1 + Lr3 + Lr34 (Л56, Л57).

Большинство идентифицированных чужеродных $L r$-генов находятся в группах сцепления с эффективными генами устойчивости к другим болезням. В одной транслокации с Lr19 присутствует высокоэффективный ген устойчивости к стеблевой ржавчине Sr25. Ржаная транслокация 1BL.1RS наряду с геном Lr26 содержит гены устойчивости к мучнистой poce $(P m 8)$, стеблевой $(S r 31)$ и желтой $(\operatorname{Yr} 9)$ ржавчине, а транслокация с 
геном Lr37, переданная от Ae. ventricosa, - гены устойчивости к стеблевой $(S r 38)$ и желтой ( $\operatorname{rr17})$ ржавчине, церкоспореллезной корневой гнили (Pch2) и злаковой цистообразующей нематоде (Cre5). Ген Lr34 тесно сцеплен с генами устойчивости к мучнистой росе $(P m 38)$, стеблевой ржавчине $(S r 57)$ и желтой ржавчине $(\operatorname{Yr} 18)(12,42)$. Линии с этими транслокациями будут иметь групповую устойчивость к нескольким болезням.

Изучение вирулентности патогена. Наряду с иммунологическими исследованиями интрогрессивных линий яровой пшеницы, в 2017 и 2018 годах мы провели мониторинг вирулентности саратовской популяции P. triticina. Инфекционный материал был собран с восприимчивых сортов, произрастающих в общем посеве с изучаемым набором линий. При инокуляции тестерных Lr-линий сборной популяцией P. triticina в оба года исследований высокой эффективностью обладали гены $L r 9$, Lr24, Lr28, Lr29, Lr39(=Lr41), Lr42, Lr45, Lr47, Lr50, Lr51, Lr53, Lr6Agi (тип реакции 0 и 0;). Линии с Lr28, Lr29, Lr39, Lr51, Lr6Agi также характеризовались высокой устойчивостью в полевых условиях. Весь набор этих генов может представлять интерес для селекции в Поволжье и расширения генетического разнообразия выращиваемых сортов пшеницы. На линиях Thatcher с генами Lr44, Lr57 наблюдали умеренно устойчивый тип реакции 2, 2++. Все остальные линии показали восприимчивость при разной интенсивности поражения.

В 2017 году на 20 изогенных $L r$-линиях было изучено 45 монопустульных изолятов патогена, в 2018 году - 35 изолятов. Изоляты, вирулентные для линии TcLr19, имели умеренную представленность (2017 год $16 \%, 2018$ год - $20 \%$ ). Частота вирулентности патогена для линии TcLr26 была высокой (2017 год - 80\%, 2018 год - 77 \%). Все изоляты, вирулентные в отношении Lr19, оказались авирулентными в случае Lr26. Beроятно, эта комбинация генов является «запретной» для патогена. Подтверждением этому могут быть результаты иммунологических исследований и высокая устойчивость интрогрессивных линий Л10, Л13, Л28, Л46 и других, несущих сочетание $L r 19+L r 26$. Существенное варьирование частот патогена по годам наблюдалось на линиях с генами $L r 2 a, L r 2 b, L r 2 c$, $\operatorname{Lr} 15$ (2017 год - $20 \%, 2018$ год - $100 \%)$. Частоты вирулентности патогена на линиях с генами Lr1, Lr3a, Lr3bg, Lr3ka, Lr10, Lr11, Lr14a, Lr14b, $\operatorname{Lr16}, \operatorname{Lr} 17, \operatorname{Lr} 18, \operatorname{Lr} 20$ и Lr30 были стабильно высокими в оба года исследований $(100 \%)$. Этим объясняется высокое поражение сортов и линии Л10 с геном $\operatorname{Lr} 10$ в фазы проростков и взрослых растений. Однако вышеперечисленные $L r$-гены могут показывать аддитивный эффект в сочетании с геном возрастной устойчивости Lr34 в повышении полевой устойчивости. Такие факты описаны в литературе (54) и отмечены в нашем исследовании для линий Л56 и Л57. В 2017 году изученная саратовская популяция, собранная на селекционном посеве НИИСХ ЮВ, была представлена тремя фенотипами вирулентности (расами) патогена (МНTKH, TGTTT, THTTR), а в 2018 году - двумя (TGTTT и THTTR).

Фенотип THTTR относится к группе широко распространенных по всей территории России и обнаруживается практически ежегодно. Все устойчивые линии в нашем исследовании характеризовались иммунностью к этому фенотипу. Фенотип TGTTT наиболее приурочен к поволжским популяциям, при этом он отмечен также в других российских регионах (55). Его неодинаковая представленность в саратовской популяции по годам исследований может служить объяснением варьирования степени пораженности сортов и линий с геном Lr19 в разные годы.

Таким образом, нами охарактеризован генетический контроль ус- 
тойчивости к бурой ржавчине (возбудитель Puccinia triticina Erikss.) у нового перспективного селекционного материала, сочетающего устойчивость к листовой ржавчине с адаптивностью к неблагоприятным факторам среды, продуктивностью и качеством зерна. Его отличительная особенность заключается в широком использовании генов устойчивости к листовой ржавчине от родственных видов. Определены линии с эффективными в условиях Нижнего Поволжья генами устойчивости (Lr29), мало используемые в селекции на территории России. Выявлены линии с эффективными комбинациям известных $L r$-генов и с комбинациями известных $L r$-генов с предположительно новыми чужеродными генами. Чужеродные гены перенесены из сортов твердой пшеницы, Triticum persicum, T. timopheevii и T. kiharae, то есть как из первичного, так и из вторичного генпула мягкой пшеницы. Использование в эффективных комбинациях генов $\operatorname{Lr} 19, \operatorname{Lr} 26, \operatorname{Lr} 34, \operatorname{Lr} 37$, сцепленных с эффективными генами устойчивости к другим болезням, будет определять устойчивость новых линий к комплексу заболеваний, что повышает ценность таких комбинаций. Определен состав популяции возбудителя бурой ржавчины в Саратовской области и показаны его изменения в течение 2017-2018 годов. Эта информация станет ключевой для планирования и проведения работ по опережающей селекции на устойчивость к бурой ржавчине.

\section{ЛИТЕРАТУРА}

1. Лебедев В.Б. Ржавчина пшеницы в Нижнем Поволжье. Саратов, 1998.

2. Крупнов В.А. Стратегия генетической защиты пшеницы от листовой ржавчины в Поволжье. Вестник РАСХН, 1997, 6: 12-15.

3. Сюков В.В. Листовая бурая ржавчина: фитопатологические и селекционно-генетические аспекты. Самара, 2016.

4. Сибикеев С.Н., Крупнов В.А. Эволюция листовой ржавчины и защита от нее пшеницы в Поволжье. Вестник Саратовского госагроуниверситета им. Н.И.Вавилова, 2007, спецвыпуск: 92-94.

5. Шехурдин А.П. Селекция и семеноводство яровой пшеницы на Юго-Востоке. Избранные труды. М., 1961.

6. Дружин А.Е., Сибикеев С.Н., Крупнов В.А. Увеличение генетического разнообразия саратовских пшениц методами интрогрессивной селекции как развитие идей Н.И. Вавилова. Вестник Саратовского госагроуниверситета им. Н.И.Вавилова, 2012, 10: 33-38.

7. Маркелова Т.С. Изучение структуры и изменчивости популяций бурой ржавчины пшеницы в Поволжье. Агро ХХI, 2007, 4-6: 37-39.

8. Иванова О.В., Маркелова Т.С. Динамика структуры популяции Puccinia recondita f. sp. tritici Rob. et Desm. в Поволжье. Защита и карантин растений, 2011, 9: 20-21.

9. Конькова Э.А. Структура популяции Puccinia triticina Erikss. на посевах озимой и яровой мягкой пшеницы в Саратовской области. Вестник защиты растений, 2018, 4(98): 44-49 (doi: 10.31993/2308-6459-2018-4(98)-44-49).

10. Михайлова Л.А. Генетика взаимоотношений возбудителя бурой ржавчины и пшеницы. СПб, 2006.

11. Sibikeev S.N., Druzhin A.E. The genetic control of leaf rust resistance in the new spring bread wheat introgression lines. Annual Wheat Newsletter, 2014, 60: 121.

12. Sibikeev S.N., Druzhin A.E., Badaeva E.D., Rouban A.S. Using of the gene pool of bread wheat wild relatives for production of collection of newly identified introgressive spring bread wheat lines resistant to the main pathogens. Annual Wheat Newsletter, 2016, 62: 53.

13. Wheat rusts. An atlas of resistance genes /R.A. McIntosh., C.R. Wellings, R.F. Park (eds.). CSIRO Publications, Australia, 1995.

14. Qiu J.W., Schürch A.C., Yahiaoui N., Dong L.L., Fan H.J., Zhang Z.J., Keller B., Ling H.Q. Physical mapping and identification of a candidate for the leaf rust resistance gene Lr1 of wheat. Theor. Appl. Genet., 2007, 115(2): 159-168 (doi: 10.1007/s00122-007-0551-z).

15. Herrera-Foessel S.A., Singh R.P., Huerta-Espino J., William M., Rosewarne G., Djurle A., Yuen J. Identification and mapping of $L r 3$ and a linked leaf rust resistance gene in durum wheat. Crop Science, 2007, 47(4): 1459-1466 (doi: 10.2135/cropsci2006.10.0663).

16. Gupta S.K., Charpe A., Koul S., Prabhu K.V., Haq Q.M. Development and validation of mo- 
lecular markers linked to an Aegilops umbellulata-derived leaf rust resistance gene, $\operatorname{Lr} 9$, for markerassisted selection in bread wheat. Genome, 2005, 48(5): 823-830 (doi: 10.1139/G05-051).

17. Cheełkowski J., Golka L., Stepien L. Application of STS markers for leaf rust resistance genes in near-isogenic lines of spring wheat cv. Thatcher. J. Appl. Genet., 2003, 44(3): 323-338.

18. Gupta S.K., Charpe A., Prabhu K.W., Haque O.M.R. Identification and validation of molecular markers linked to the leaf rust resistance gene Lr19 in wheat. Theor. Appl. Genet., 2006, 113(6): 1027-1036 (doi: 10.1007/s00122-006-0362-7).

19. Neu C., Stein N., Keller B. Genetic mapping of the Lr20-Pm1 resistance locus reveals suppressed recombination on chromosome arm 7AL in hexaploid wheat. Genome, 2002, 45(4): 737 744 (doi: 10.1139/g02-040).

20. Hiebert C.W., Thomas J.B., Somers D.J., McCallum B.D., Fox S.L. Microsatellite mapping of adult-plant leaf rust resistance gene Lr22a in wheat. Theor. Appl. Genet., 2007, 115(6): 877-884 (doi: 10.1007/s00122-007-0604-3).

21. Mago R., Zhang P., Bariana H.S., Verlin D.C., Bansal U.K., Ellis J.G., Dundas I.S. Development of wheat lines carrying stem rust resistance gene Sr39 with reduced Aegilops speltoides chromatin and simple PCR markers for marker-assisted selection. Theor. Appl. Genet., 2009, 119(8): 1441-1450 (doi: 10.1007/s00122-009-1146-7).

22. Weng Y., Azhaguvel P., Devkota R.N., Rudd J.C. PCR-based markers for detection of different sources of 1AL.1RS and 1BL.1RS wheat-rye translocations in wheat background. Plant Breed., 2007, 126(5): 482-486 (doi: 10.1111/j.1439-0523.2007.01331.x).

23. Cherukuri D.P., Gupta S.K., Charpe A., Koul S., Prabhu K.V., Singh R.B., Haq Q.M.R. Molecular mapping of Aegilops speltoides derived leaf rust resistance gene Lr28 in wheat. Euphytica, 2005, 143(1): 19-26 (doi: 10.1007/s10681-005-1680-6).

24. Procunier J.D., Townley-Smith T.F., Fox S., Prashar S., Gray M., Kim W.K., Czarnecki E., Dyck P.L. PCR-based RAPD/DGGE markers linked to leaf rust resistance genes $L r 29$ and Lr25 in wheat (Triticum aestivum L.). Journal of Genetics and Breeding, 1995, 49(1): 87-91.

25. Lagudah E.S., McFadden H., Singh R.P., Huerta-Espino J., Bariana H.S., Spielmeyer W. Molecular genetic characterization of the $\mathrm{Lr34} / \mathrm{Yr} 18$ slow rusting resistance gene region in wheat. Theor. Appl. Genet., 2006, 114(1): 21-30 (doi: 10.1007/s00122-006-0406-z).

26. Mago R., Bariana H.S., Dundas I.S. Development or PCR markers for the selection of wheat stem rust resistance genes Sr24 and Sr26 in diverse wheat germplasm. Theor. Appl. Genet., 2005, 111(3): 496-504 (doi: 10.1007/s00122-005-2039-z).

27. Helguera M., Khan I. A., Kolmer J., Lijavetzky D., Zhong-qi L., Dubcovsky J. PCR assays for the Lr37-Yr17-Sr38 cluster of rust resistance genes and their use to develop isogenic hard red spring wheat lines. Crop Science, 2003, 43(5): 1839-1847 (doi: 10.2135/cropsci2003.1839).

28. Pestsova E., Ganal M.W., Röder, M.S. Isolation and mapping of microsatellite markers specific for the D genome of bread wheat. Genome, 2000, 43(4): 689-697 (doi: 10.1139/g00-042).

29. Helguera M., Khan I.A., Dubcovsky J. Development of PCR markers for wheat leaf rust resistance gene Lr47. Theor. Appl. Genet., 2000, 100(7): 1137-1143 (doi: 10.1007/s001220051397).

30. Dadkhodaie N.A., Karaoglou H., Wellings C.R., Park R.F. Mapping genes Lr53 and Yr35 on the short arm of chromosome $6 \mathrm{~B}$ of common wheat with microsatellite markers and studies of their association with Lr36. Theor. Appl. Genet., 2011, 122(3): 479-87 (doi: 10.1007/s00122-0101462-y).

31. Marais G.F., Bekker T.A., Eksteen A., McCallum B., Fetch T., Marais A.S. Attempts to remove gametocidal genes co-transferred to common wheat with rust resistance from Aegilops speltoides. Euphytica, 2010, 171(1): 71-85 (doi: 10.1007/s10681-009-9996-2).

32. Schachermayr G.M., Messemer M.M., Feuillet C., Winzeler H., Winzeler M., Keller B. Identification of molecular markers linked to the Agropyron elongatum-derived leaf rust resistance gene Lr24 in wheat. Theor. Appl. Genet., 1995, 90(7-8): 982-990 (doi: 10.1007/BF00222911).

33. Сибикеев С.Н., Бадаева Е.Д., Гультяева Е.И., Дружин Л.Е., Шишкина А.А., Драгович А.Ю., Крупин П.Ю., Карлов Г.И., Тхи Май Кхуат, Дивашук М.Г. Сравнительный анализ $6 A g^{i}$ и $6 A g^{i} 2$ хромосом Agropyron intermedium (Host) Beauv. у сортов и линий мягкой пшеницы с пшенично-пырейными замещениями. Генетика, 2017, 53(3): 298-310 (doi: 10.7868/S0016675817030110).

34. Дорохов Д.Б., Клоке Э. Быстрая и экономичная технология RAPD анализа растительных геномов. Генетика, 1997, 33(4): 443-450.

35. Михайлова Л.А., Гультяева Е.И., Мироненко Н.В. Методы исследований структуры популяции возбудителя бурой ржавчины пшеницы. Сборник методических рекомендаций по защите растений. СПб, 1998: 105-126.

36. Гультяева Е.И., Шайдаюк Е.Л., Шаманин В.П., Ахметова А.К., Тюнин В.А., Шрейдер Е.Р., Кашина И.В., Ерошенко Л.А., Середа Г.А., Моргунов А.И. Генетическая структура российских и казахстанских популяций возбудителя бурой ржавчины Puccinia triticina Erikss. по вирулентности и SSR маркерам. Сельскохозяйственная биология, 2018, 53(1): 85-95 (doi: 10.15389/agrobiology.2018.1.85rus). 
37. Long D.L., Kolmer J.A. A North American system of nomenclature for Puccinia recondita f. sp. tritici. Phytopathology, 1989, 79(5): 525-529.

38. Ильина Л.Г. Селекция саратовских яровых пшении. Саратов, 1996.

39. Лепехов С.Б. Признаки с отрицательными эффектами и их значение для селекции мягкой пшеницы (Triticum aestivum L.). Вавиловский журнал генетики и селекции, 2016, 20(3): 337-343 (doi: 10.18699/VJ16.114).

40. Гультяева Е.И., Баранова О.А., Дмитриев А.П. Вирулентность и структура популяций Puccinia triticina в Российской Федерации в 2007 году. Вестник защиты растений, 2009, 4: 33-38.

41. Zhemchuzhina A., Kurkova N. Structure of population of Puccinia triticina in various regions of Russia in 2006-2008. Proc. of the BGRI Technical Workshop. St. Petersburg, 2010: 27.

42. McIntosh R.A., Dubcovsky J., Rogers W.J., Morris C., Xia X.C. Catalogue of gene symbols for wheat: 2017 supplement. Режим доступа: https://shigen.nig.ac.jp/wheat/komugi/genes/macgene/supplement2017.pdf. Дата обращения 25.07.2019.

43. Леонова И.Н. Влияние чужеродного генетического материала на проявление хозяйственно важных признаков мягкой пшеницы (T. aestivum L.). Вавиловский журнал генетики и селекции, 2018, 22(3): 321-328 (doi: 10.18699/VJ18.367).

44. Aktar-Uz-Zaman M., Tuhina-Khatun M., Hanafi M.M., Sahebi M. Genetic analysis of rust resistance genes in global wheat cultivars: an overview. Biotechnology \& Biotechnological Equipment, 2017, 31(3): 431-445 (doi: 10.1080/13102818.2017.1304180).

45. Берлянд-Кожевников В.М., Дмитриев А.П., Будашкина Е.Б., Шитова И.П., Рейтер Б.Г. Устойчивость пшеницы $\kappa$ бурой ржавчине (генетическое разнообразие популяций гриба $u$ растения-хозяина). Новосибирск, 1978.

46. Васильчук Н.С., Гапонов С.Н., Еременко Л.В., Паршикова Т.М., Попова В.М., Цетва Н.М., Шутарева Г.И. Итоги селекции яровой твердой пшеницы на высокое качество зерна в Саратове. Достижения науки и техники АПК, 2010, 5: 22-24.

47. Сибикеев С.Н. Чужеродные гены в селекции яровой мягкой пшеницы на устойчивость $к$ листовой ржавчине. Докт. дис. Саратов, 2002.

48. Гультяева Е.И., Орина А.С., Ганнибал Ф.Б., Митрофанова О.П., Одинцова И.Г., Лайкова Л.И. Эффективность молекулярных маркеров для выявления генов $L r 28, L r 35$ и $L r 47$ у мягкой пшеницы. Генетика, 2014, 50(2): 147-156 (doi: 10.7868/S0016675814020064).

49. Nicol J.M., Bolat N., Bagci A., Trethowan R.T., William M., Hekimhan H., Yidirim A.F., Sahin E., Eleckcioglu H., Toktay H., Tunali B., Hede A., Taner S., Braun H.J., Payne T., Ginkel M., Keser M., Arisoy Z., Yorgancilar A., Tulek A., Erdurmus D., Buyuk O., Aydogdu M. CIMMYT and Turkey's international shuttle breeding program to develop wheat lines with fusarium crown rot and other soil borne pathogen resistances. In: The global fusarium initiative for international collaboration /T. Ban, J.M. Lewis, E.E. Phipps (eds.). Mexico, El Batán, 2006: 110-116.

50. Sharma S., Ghimire S.K., Niroula R.K., Ojha B.R., Thapa D.B. Marker assisted screening of Nepalese wheat genotypes and advanced lines for resistance to different races of wheat rust species. J. Inst. Agric. Anim. Sci., 2015, 33-34: 165-175 (doi: 10.3126/jiaas.v33i0.20700).

51. Ishikawa G., Nakamura T., Ashida T., Saito M., Nasuda S., Endo T.R., Wu J., Matsumoto T. Localization of anchor loci representing five hundred annotated rice genes to wheat chromosomes using PLUG markers. Theor. Appl. Genet., 2009, 118(3): 499-514 (doi: 10.1007/s00122008-0916-y).

52. Salina E.A., Adonina I.G., Badaeva E.D., Kroupin P.Yu., Stasyuk A.I., Leonova I.N., Shishkina A.A., Divashuk M.G., Starikova E.V., Khuat T.M.L., Syukov V.V., Karlov G.I. Thinopyrum intermedium chromosome in bread wheat cultivars as a source of gene conferring resistance to fungal diseases. Euphytica, 2015, 204(1): 91-101 (doi: 10.1007/s10681-014-1344-5).

53. Романов Б.В., Авдеенко А.П. Гомология у видов пшеницы в связи с феномогеномикой их количественных признаков. Современные проблемы науки и образования, 2012, 1.

54. Dakouri A., McCallum B.D., Radovanovic N., Cloutier S. Molecular and phenotypic characterization of seedling and adult plant leaf rust resistance in a world wheat collection. Mol. Breeding, 2013, 32(3): 663-677 (doi: 10.1007/s11032-013-9899-8).

55. Гультяева Е.И., Аристова М.К., Шайдаюк Е.Л., Мироненко Н.В., Казарцев И.А., Ахметова А., Косман Е. Генетическая дифференциация Puccinia triticina Erikss. на территории России. Генетика, 2017, 53(9): 1053-1060 (doi: 10.7868/S0016675817070037).

1 ФГБНУ Всероссийский НИИ защиты растений,

196608 Россия, г. Санкт-Петербург-Пушкин, ш. Подбельского, 3, e-mail: eigultyaeva@gmail.com $₫$, eshaydayuk@bk.ru;

2ФГБНУ НИИ сельского хозяйства Юго-Востока,

410010 Россия, г. Саратов, ул. Тулайкова, 7,

e-mail: sibikeev_sergey@mail.ru, alex_druzhin@mail.ru
Поступила в редакцию 3 сентября 2019 года 


\title{
ENLARGEMENT OF GENETIC DIVERSITY OF SPRING BREAD WHEAT RESISTANCE TO LEAF RUST (Puccinia triticina Eriks.) IN LOWER VOLGA REGION
}

\author{
E.I. Gultyaeva1, S.N. Sibikeev², A.E. Druzhin', E.L. Shaydayuk ${ }^{1}$ \\ ${ }^{1}$ All-Russian Research Institute of Plant Protection, 3, sh. Podbel'skogo, St. Petersburg, 196608 Russia, e-mail eig- \\ ultyaeva@gmail.com ( $\square$ corresponding author), eshaydayuk@bk.ru; \\ ${ }^{2}$ Agricultural Research Institute for South-East Regions, 7, ul. Tulaikova, Saratov 410010 Russia, e-mail sibi- \\ keev_sergey@mail.ru, alex_druzhin@mail.ru \\ ORCID: \\ Gultyaeva E.I. orcid.org/0000-0001-7948-0307 \\ Druzhin A.E. orcid.org/0000-0002-3968-2470 \\ Sibikeev S.N orcid.org/0000-0001-8324-9765 \\ The authors declare no conflict of interests \\ Shaydayuk E.L. orcid.org/0000-0003-3266-6272 \\ Acknowledgements: \\ Supported financially by the Russian Foundation for Basic Research, project No. 18-016-00170 \\ Received September 3, 2019 \\ doi: $10.15389 /$ agrobiology.2020.1.27eng
}

\section{Abstract}

Leaf rust (Puccinia triticina Eriks.) is the significant disease of winter and spring wheat in Russia. In the Volga region, the epiphytoties of this disease are observed on average once per three to four years. The genetic protection of wheat from leaf rust is a priority. Its successful practical implementation is possible only by the increasing of the genetic diversity of the commercial wheat cultivars, particularly by effective combinations of the known genes for resistance or use in the hybridization donors of new Lr-genes, from species of genera Triticum and Aegilops. On the basis of highly productive and adaptive spring bread wheat cultivars (Prokhorovka, Saratovskaya 29, Saratovskaya 55, Saratovskaya 68, Saratovskaya 70, Saratovskaya 73, Saratovskaya 74, L503, L505, Dobrynya, Favorite, Belyanka, Voevoda of Saratov Breeding Center) and alien species the introgression lines are derived which possess high resistance to leaf rust and are promising as breeding material. It was of interest to study the genetic determination of leaf rust resistance in these new lines and to evaluate their effect on the variability of $P$. triticina population for virulence in Saratov region. A total of 42 introgression lines were investigated. Donors of alien $L r$-genes were the lines of cultivar Thahcher with Lr24, Lr29, Lr36 genes, and cultivars with Lr37 gene, and also species Triticum dicoccum, T. kiharae, T. timopheevii, T. durum, T. petropavloskyi, T. persicum, Aegilops tauschii, Secale sereale and Agropyron elongatum. Leaf rust resistance genes ( $\mathrm{r} r$-genes) were identified by phytopathological tests and DNA markers. The studied lines of spring bread wheat showed high genetic diversity for leaf rust resistance. Among them, we have identified the carriers of known $L r$-genes which have not yet been used in breeding of spring bread wheat in Russia (L4 with Lr29), and also the carriers of presumably new $L r$-genes transferred from $T$. durum (L8, L39 for Lr19 + LrTdur, L25, L19, L11 for Lr10 + Lr19 + LrTdur), T. persicum (L38 for Lr19 + LrT.pers), T. timopheevii (L49 for Lr10 + LrT.tim), Ae. tauschii (L6 for Lr19 + LrA.tau), and T. kiharae (L33 for Lr3 + Lr19+LrT.kh). Lines L10, L13, L46, L24, L48, L5 and L9 have the effective combination of Lr19+ Lr26 genes, L2, L28 L29 of Lr10 + Lr19 + Lr26, L42 of Lr19+Lr37, L44 of Lr19+Lr26+Lr39, L3 of Lr19+Lr37+Lr6Agi, L4 of Lr19 + Lr6Agi, L7 of Lr10 + Lr26 + Lr6Agi, L45 of Lr10 + Lr19+Lr39+Lr6Agi, and L40 of Lr10 + Lr39 + Lr6Agi. The virulence of the pathogen of the Saratov population was characterized in 2017 and 2018. The samples were collected from susceptible wheat cultivars which grew together with the studied introgression lines. The $\operatorname{Lr} 9, \operatorname{Lr} 24, \operatorname{Lr} 28, \operatorname{Lr} 29, \operatorname{Lr} 41, \operatorname{Lr} 42, \operatorname{Lr} 45, \operatorname{Lr} 47, \operatorname{Lr} 50, \operatorname{Lr} 51$, Lr53, and Lr6Agi genes (infection type 0 and 0;) were highly effective. Lines with $\operatorname{Lr} 28, \operatorname{Lr} 29, \operatorname{Lr} 4$, Lr51, and Lr6Agi genes also showed high resistance under field conditions. Thus, all these genes are perspective for breeding in the Volga region to expand genetic diversity of wheat cultivars. The presence of the isolates virulent to TcLr19 lines was moderate, $16 \%$ in 2017 and $20 \%$ in 2018. All isolates virulent to $\operatorname{Lr} 19$ were avirulent to $L r 26$, which confirms the effectiveness of this combination of $L r$-genes in plant protection from leaf rust. This research resulted in a novel breeding material that combines resistance to leaf rust with adaptability to environmental factors, productivity and grain quality. Its distinctive feature is new donors of resistance involved from related species. Among tested lines there are donors which effectively combine either known $L r$-genes or known and supposedly new alien $L r$-genes. The linkage of $\operatorname{Lr} 19, \operatorname{Lr} 26, \operatorname{Lr} 34, \operatorname{Lr} 37$ genes with effective genes for resistance to other diseases, in particular to stem rust, will determine the resistance of new lines to a complex of diseases.

Keywords: Puccinia triticina, virulence, avirulence, Triticum aestivum, introgression lines, Lr-genes. 